\title{
Preliminary Evaluation of Adherence on Abiotic and Cellular Surfaces of Acinetobacter baumannii Strains Isolated from Catheter Tips
}

\author{
Gislaine Franco de Moura Costa ${ }^{1}$, \\ Maria Cristina Bronharo Tognim², \\ Celso Luíz Cardoso², \\ Floristher Elaine Carrara-Marrone ${ }^{3}$ \\ and Lourdes Botelho Garcia ${ }^{2}$
}

\author{
${ }^{1}$ Center of Medical and Pharmaceutical Sciences, State University of \\ West of Paraná, Cascavel, PR, Brazil; ${ }^{2}$ Department of Clinical Analyses, \\ State University of Maringá, Maringá, PR, Brazil; ${ }^{3}$ Department of \\ Pathology, Clinical and Toxicological Analyses, University Hospital, \\ State University of Londrina, Londrina, PR, Brazil
}

The cell surface hydrophobicity and adhesion to abiotic and cellular surfaces was tested in five clinical strains of Acinetobacter baumannii isolated from catheter tips. Biochemical and molecular characteristics of these strains were also studied. Hydrophobicity was characterized by a test for affinity to xylene. Adhesion to abiotic surfaces (polystyrene, formica, latex and glass) was evaluated in Petri plates using the stamp technique. Buccal epithelial cells were used for tests of adhesion to cellular surfaces. Adhesion to the catheter was evaluated by repeatedly rinsing the catheters and rolling them over nutrient agar. Molecular typing of the strains was done by the ERIC-PCR technique. The degree of hydrophobicity of the strains varied from hydrophobic to hydrophilic. All the strains adhered to the cell surfaces and to the catheters, and three of them strongly adhered to latex, polystyrene and formica. Catheter adhesion was reduced by meropenem. We found a direct relationship between the degree of bacterial hydrophobicity and adhesion to the abiotic surfaces, but not with adhesion to cellular surfaces, which suggests that different mechanisms are involved in adherence. Key Words: Acinetobacter baumannii, hydrophobicity, adherence.

During the last few years, infections involving species of Gram-negative non-enteric and multidrug-resistant bacilli have increased [1]. Among these bacteria, Acinetobacter spp. have proven to be among the most important pathogens; they are frequently involved in serious hospital infection outbreaks $[2,3]$.

Acinetobacter spp. are widely distributed in hospital environments and are frequently isolated from the skin of hospital staff, inanimate surfaces and equipment [4-8]. This, together with the multiple resistance of these organisms to therapeutic antimicrobial agents, can result in serious infections in debilitated patients [9]. In humans, the main sites of infection are the respiratory tract, followed by the bloodstream, less often involving the urinary tract, surgical wounds, the central nervous system, skin, and eyes [10,11].

The ability of acinetobacter strains to adhere to surfaces is an important mechanism in the pathogenicity of these bacteria. Although adhesion ability is determined by specific factors, such as adhesins, and non-specific factors, such as hydrophobicity and cellular surface electrical discharge, it varies among strains [12] and may be affected by antimicrobial agents [13].

Received on 3 June 2006; revised 30 September 2006.

Address for correspondence: Dr. Lourdes Botelho Garcia. Departamento de Análises Clínicas, Universidade Estadual de Maringá, Avenida Colombo, 5790, Zip code: 87020-900, Maringá, PR, Brazil. E-mail: lbgarcia@uem.br. Phone: + 55 (44) 3261-4952. Fax: + 55 (44) 3261-4860.

The Brazilian Journal of Infectious Diseases 2006;10(5):346-351. (C) 2006 by The Brazilian Journal of Infectious Diseases and Contexto Publishing. All rights reserved.
Considering that Acinetobacter baumannii is frequently found in hospital environments, and that little is known about the mechanisms of pathogenicity of this important nosocomial pathogen, we studied the degree of cellular hydrophobicity and adhesion ability to abiotic and cellular surfaces of five strains of Acinetobacter baumannii isolated from intravascular catheter tips. Their biochemical and molecular characteristics were also studied.

\section{Material and Methods}

$\underline{\text { Strains }}$

Five strains of Acinetobacter baumannii were used; these were isolated in April and June 1994 from catheter tips of patients hospitalized at the University Hospital of the State University of Londrina, in the city of Londrina, Paraná State, Brazil. The strains were initially stored in a freezer at $-20^{\circ} \mathrm{C}$. Before use, they were inoculated in tryptic soy broth (TSB) (Difco Laboratories, Sparks, Maryland, USA) and incubated at $35-37^{\circ} \mathrm{C}$ for 24 hours. The identification of the strains was confirmed by using a 16-test system (acid production of glucose, gelatin hydrolysis, and utilization of 14 carbon sources) associated with tests for growth at $37^{\circ} \mathrm{C}, 41^{\circ} \mathrm{C}$, and $44^{\circ} \mathrm{C}[14]$.

For molecular typing, bacterial DNA was extracted according to Donald et al. [16], with some modifications. Briefly, the primers used for the reaction processing were ERIC1 5 , ATGTAAGCTCCTGGGGATTCAC 3' and ERIC2 5' AAGTAAGTGACTGGGGTGAGCG 3' [17,18]. A 100 bp DNA Mass Ladder $1 \mu \mathrm{g} / \mu \mathrm{L}$ (Invitrogen Life Technologies, Rockville, Maryland, USA) was used as a marker for molecular weight. The gel was dyed with ethidium bromide $(0.5 \mu \mathrm{g} / \mathrm{mL})$, and was 
observed and photographed under ultraviolet light (320 nm) (BioRad, California, USA). Genetic divergence between the strains was estimated with a simple matching coefficient by using the program Numerical Taxonomy and Multivariate Analysis System (NTSYS-PC version 1.7) [15].

\section{Bacterial cell surface hydrophobicity}

Hydrophobicity was determined by an affinity test to xylene [19], with bacterial cells from cultures in nutrient broth (Difco), previously incubated at $35-37^{\circ} \mathrm{C}$ for 24 hours.

Four triplicate tests were carried out for each strain, and the results were used to calculate the hydrophobicity index (HI), using the equation: $\mathrm{HI}=\left(\mathrm{A}_{660}-\mathrm{B}_{660}\right) \times 100 / \mathrm{A}_{660}$, where $\mathrm{A}_{660}$ represents the optical density of the bacterial suspension before treatment with xylene, and $\mathrm{B}_{660}$ represents the optical density of the aqueous phase after treatment of the bacterial suspension with xylene.

The strains were considered as strongly hydrophobic when the hydrophobicity index was above $70 \%$, and hydrophilic when the hydrophobicity index was below $30 \%$, [20]. The results were compared using the Student's $t$ test at a $5 \%$ significance level.

Bacterial adhesion to latex, polystyrene, formica and glass

The strains were cultivated at $35-37^{\circ} \mathrm{C}$ in Petri plates containing nutrient agar (Difco). After 48 hours of incubation, the cultures were photographed and then, using the stamp technique, the bacteria were transferred to latex, polystyrene, formica and glass surfaces by pressing each material against the culture surfaces for five seconds [21].

Photographic images of the Petri dishes with the original bacterial growth and those from the stamps were compared. The capacity of adhesion to the glass, polystyrene, formica and latex was evaluated according to the following criteria (-) non-adherent strain; $(+)$ strain with weak adhesion; $(++)$ moderate adhesion; $(+++)$ good adhesion, $(++++)$ strong adhesion. The experiments were carried out in duplicate. The strains Acinetobacter baumannii ATCC 14606 and Escherichia coli $\mathrm{Hb} 101$ were used as the test's positive and negative controls, respectively.

\section{Bacterial adhesion to intravascular catheters and the effect of meropenem}

The in vitro study of bacterial adhesion to the catheter was undertaken according to the methodology established by Sheth et al. [22], with some modifications. The strains selected for this study were cultivated for 18-24 hours at 35$37^{\circ} \mathrm{C}$ in a nutrient broth (Difco) containing $1 / 4$ or $1 / 2$ of the minimum inhibitory concentration (MIC) of meropenem. After the incubation period, the antimicrobial agent was removed from the cultures by rinsing twice with a sterile $0.85 \%$ saline solution and centrifugation. Next, the bacterial cells were resuspended in sterile saline solution, and the optical density of each suspension was measured $(540 \mathrm{~nm})$ and adjusted to
$0.10 \mathrm{U}$ (equivalent to $10^{7} \mathrm{CFU} / \mathrm{mL}$ ). Cultures without antibiotics were used as controls.

Intravascular catheters (Intracath ${ }^{\circledR}$, Becton Dickinson, Sandy, Utah, USA), $1.7 \mathrm{~mm}$ in diameter were cut into $1.5-\mathrm{cm}$ long segments with sterile scissors. The segments were then immersed in $13 \times 100 \mathrm{~mm}$ tubes containing the suspensions of the previously-standardized strains and kept at room temperature for 30 minutes.

After this contact, each fragment was placed in an 18x160$\mathrm{mm}$ tube containing $15 \mathrm{~mL}$ of sterile saline solution, and the tube was manually inverted 40 times. This procedure was repeated 15 times, transferring the fragment to 15 tubes successively, with the objective of removing the non-adhered bacteria.

After the $15^{\text {th }}$ rinse, the catheter fragment was removed from the tube and rolled over the surface of ten $90 \times 15-\mathrm{mm}$ Petri plates containing nutrient agar (Difco). After an incubation period of $18-24$ hours at $35-37^{\circ} \mathrm{C}$, the bacteria colonies were counted. The number of colonies indirectly showed the number of bacteria adhered to the catheter. The final result was represented by $\log _{10}$ of the number of bacteria that adhered to the catheter, using the following formula: catheter surface area $=\pi \mathrm{x}$ diameter $\mathrm{x}$ length of catheter.

The reduction in the adhesion rate to the catheter of the cultures treated with $1 / 4$ and $1 / 2$ MIC of meropenem was determined by calculating the logarithm reduction factor (LRF), i.e., $\log _{10}$ of the mean counts of the control culture (no antibiotics) minus $\log _{10}$ of the mean counts of cultures treated with antibiotics. The percentage reduction in the number of bacteria adhered to the catheter was calculated for all cultures treated with antibiotics, using the mean count of the control culture as a reference $(100 \%)$. Three duplicate experiments were carried out for each bacterial strain. The data were compared by Student's t test at a 5\% significance level.

\section{Bacterial adhesion to buccal epithelial cells}

The test of bacterial adhesion to epithelial cells was carried out in vitro, using bacterial cultures in solidified media and epithelial cells from human buccal membranes [23]. Negative controls with epithelial cells were included in each experiment, replacing the bacterial suspension with a buffered suspension. The bacterial cells' adhesion capacity was determined by counting the number of bacteria adhered to the epithelial cells, observing 100 cells in each Gram-stained slide preparation. Two adhesion experiments were carried out for each bacterial strain, totaling six slides and adhered bacteria counts were made of 600 epithelial cells.

\section{Results}

Molecular typing demonstrated three distinct clones (Figures 1 and 2). Strains 09T and 16T belonged to the same clone, with $100 \%$ similarity (Clone A). Strains 10T and 15T were considered as being the same clone, because the similarity 
Figure 1. Comparative Dendrogram of the profile presented by the five strains of Acinetobacter baumannii based on DNA analysis carried out with the ERIC PCR test.

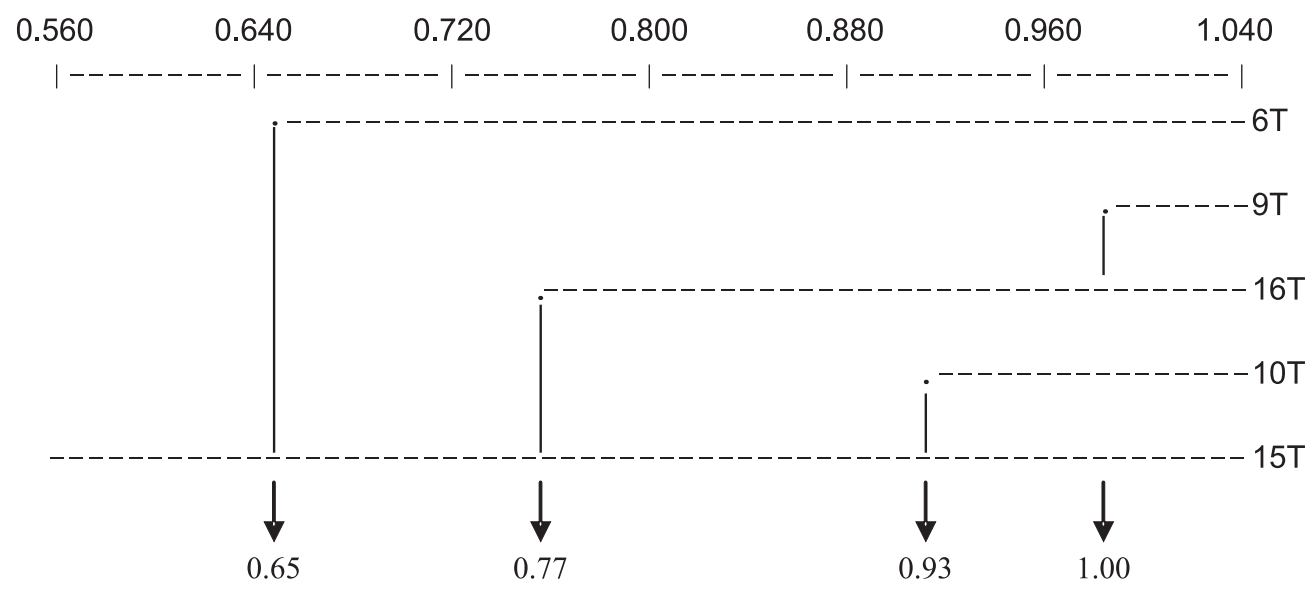

Figure 2. Molecular profile of the strains of Acinetobacter baumannii in $1.5 \%$ agarose gel obtained by ERIC-PCR methodology.

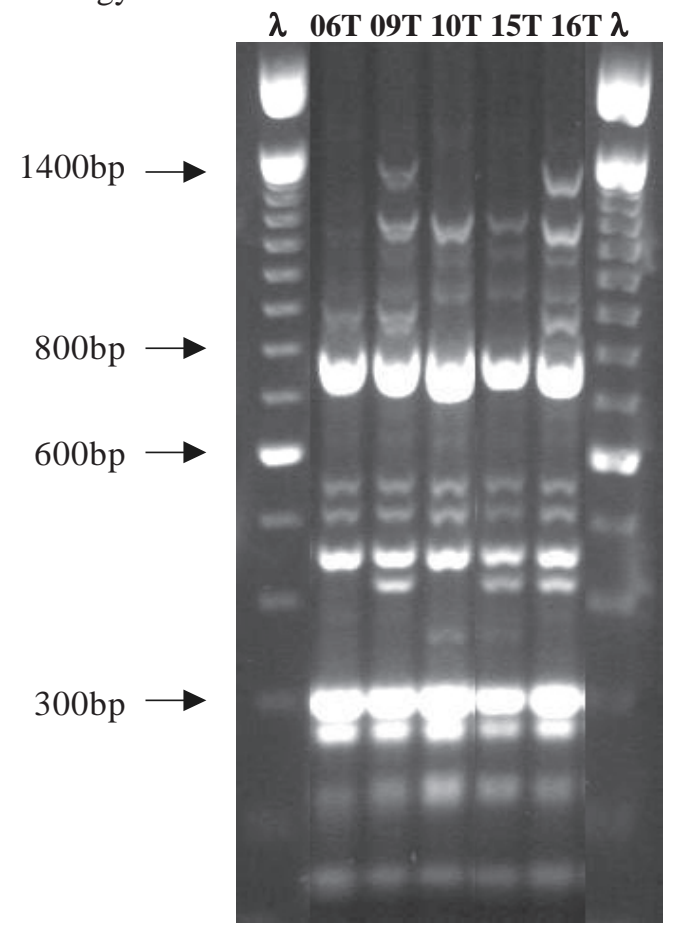

between them was over $90 \%$ (Clone B). Clones A and B had lower similarity with each other (77\%), and both were distinct from the clone of strain 06T (Clone $\mathrm{C}$ ), with just 65\% similarity.

Two strains (06T, 15T) were highly hydrophobic, two (10T, 16T) showed medium hydrophobicity, and one (09T) was hydrophilic. A lack of significant differences in the mean hydrophobicity index was only found between strains $10 \mathrm{~T}$ and $16 \mathrm{~T}(\mathrm{P}=0.09$, Table 1$)$.

The adhesion test with different materials gave variable adhesion pattern results. All the strains adhered to latex, polystyrene and formica. However, samples $15 \mathrm{~T}$ and $16 \mathrm{~T}$ did not adhere to glass, and samples 06T, 09T and 10T adhered only weakly to glass (Table 2).

The number of bacteria from the control cultures that adhered per $\mathrm{cm}^{2}$ of catheter varied from 2,100 $\left(3.32 \log _{10}\right)$ to $4,700\left(3.67 \log _{10}\right)$. Treatment of cultures with meropenem significantly reduced the adhesion ability of all the strains $(P$ $<0.05$, Table 3$)$. The $1 / 4 \mathrm{MIC}$ concentration reduced adhesion ability $45.1 \%$ (strain 9T), 45.8\% (strain 15T), 68.1\% (strain 10T), 70\% (strain 16T) and $91.4 \%$ (strain 6T). The same strains cultivated in a medium containing $1 / 2$ MIC gave reduction percentages between 76.5 and $95.3 \%$. Strain $6 \mathrm{~T}$ was the only one of the five strains that showed a logarithm reduction factor above 1.0 for both sub-minimum inhibitory concentrations of meropenem.

All five strains adhered to the buccal mucosa cells to the same degree or more than the standard strain (Table 4). The negative control of these tests corresponded to a microscopic observation of 2,100 epithelial cells, with a mean of 2.24 adhered bacteria per cell.

\section{Discussion}

In recent decades, bacteria of the Acinetobacter genus have become important all over the world, including Brazil, because of their multi-drug resistance to antimicrobial agents and their increasing involvement in hospital infections $[2,24,26]$. These microorganisms are responsible for infectious processes at different sites, the bloodstream being one of the most frequently attacked $[10,11]$. Thus, materials that come into direct contact with the patients' circulatory bloodstream, such as intravascular catheters, should be investigated for this bacterium [27].

The increasing participation of A. baumannii in the etiology of nosocomial infections has stimulated studies of this bacterium pathogenicity mechanisms. Hydrophobicity has been associated 
Table 1. Hydrophobicity Index (mean \pm standard deviation) of the cellular surface of five strains of Acinetobacter baumannii, determined by the microbial adhesion method to hydrocarbonates (xylene)

\begin{tabular}{|c|c|c|c|}
\hline Strain & Optical density $\mathbf{A}^{1}$ & Optical density $\mathbf{B}^{2}$ & Hydrophobicity index ${ }^{3}$ \\
\hline $06 \mathrm{~T}$ & $0.3895 \pm 0.0090$ & $0.0589 \pm 0.0349$ & $84.7626 \pm 9.2809$ \\
\hline 09T & $0.4006 \pm 0.0054$ & $0.2963 \pm 0.0289$ & $26.0679 \pm 6.5886$ \\
\hline $10 \mathrm{~T}$ & $0.4044 \pm 0.0131$ & $0.2587 \pm 0.0387$ & $36.0511 \pm 9.0790$ \\
\hline $15 \mathrm{~T}$ & $0.3935 \pm 0.0073$ & $0.0393 \pm 0.0009$ & $90.0006 \pm 0.2949$ \\
\hline $16 \mathrm{~T}$ & $0.4051 \pm 0.0068$ & $0.2787 \pm 0.0271$ & $31.2933 \pm 5.8756$ \\
\hline A. baumannii ${ }^{4}$ & $0.4143 \pm 0.0269$ & $0.2843 \pm 0.0251$ & $32.3608 \pm 5.2772$ \\
\hline E. coli $\mathrm{Hb} 101^{5}$ & $0.4088 \pm 0.0216$ & $0.3724 \pm 0.0156$ & $8.78 \pm 4.1305$ \\
\hline
\end{tabular}

${ }^{1} \mathrm{~A}=$ Optical density $\left(\mathrm{A}_{660}\right)$ of the bacterial suspension before treatment with xylene. ${ }^{2} \mathrm{~B}=$ Optical density $\left(\mathrm{A}_{660}\right)$ of the aqueous phase after treatment of the bacterial suspension with xylene. ${ }^{3}$ Hydrophobicity Index $=\left(\mathrm{A}_{660}-\mathrm{B}_{660}\right) \times 100 /$ $\mathrm{A}_{660}{ }^{4}$ ATCC 14606.

Table 2. The results of bacterial adhesion tests to the surfaces of different materials

\begin{tabular}{lcccc}
\hline \multirow{2}{*}{ Strain } & \multicolumn{4}{c}{ Adherence ${ }^{1}$ to } \\
\cline { 2 - 5 } & Latex & Polystyrene & Formica & Glass \\
\hline $06 \mathrm{~T}$ & ++++ & +++ & +++ & + \\
$09 \mathrm{~T}$ & ++ & ++ & ++ & + \\
$10 \mathrm{~T}$ & ++ & +++ & +++ & + \\
$15 \mathrm{~T}$ & ++++ & ++ & + & - \\
$16 \mathrm{~T}$ & ++ & +++ & +++ & - \\
Acinetobacter baumannii $^{2}$ & ++++ & - & - & + \\
E. coli Hb101 $^{3}$ & - & & ++ & - \\
\hline
\end{tabular}

${ }^{1}$ Criteria: (-) non-adherent strains; (+) weak adhesion; (++) moderate adhesion; (+++) good adhesion; (++++) strong adhesion. ${ }^{2}$ ATCC 14606. Positive Control. ${ }^{3}$ Negative Control.

Table 3. $\log _{10}$ of the number of Acinetobacter baumannii adhered to catheter sections, and the logarithm reduction factor (LRF) of the strains treated with $1 / 4$ and $1 / 2$ of MIC of meropenem

\begin{tabular}{|c|c|c|c|c|c|}
\hline \multirow[t]{2}{*}{ Strain } & \multirow{2}{*}{$\frac{\text { Control }}{\text { Mean } \pm \text { SD }}$} & \multicolumn{2}{|c|}{ Culture 1/4 MIC } & \multicolumn{2}{|c|}{ Culture 1/2 MIC } \\
\hline & & Mean \pm SD & $\mathrm{LRF} \pm \mathrm{SD}$ & Mean \pm SD & $\mathbf{L R F} \pm \mathrm{SD}$ \\
\hline $06 \mathrm{~T}$ & $3.44 \pm 0.03$ & $2.37 \pm 0.05$ & $1.07 \pm 0.02$ & $2.11 \pm 0.04$ & $1.33 \pm 0.01$ \\
\hline 09T & $3.36 \pm 0.08$ & $3.11 \pm 0.05$ & $0.25 \pm 0.03$ & $2.72 \pm 0.16$ & $0.64 \pm 0.08$ \\
\hline $10 \mathrm{~T}$ & $3.61 \pm 0.02$ & $3.11 \pm 0.03$ & $0.50 \pm 0.01$ & $2.38 \pm 0.04$ & $1.23 \pm 0.02$ \\
\hline $15 \mathrm{~T}$ & $3.67 \pm 0.07$ & $3.36 \pm 0.23$ & $0.31 \pm 0.16$ & $2.62 \pm 0.21$ & $1.05 \pm 0.05$ \\
\hline $16 \mathrm{~T}$ & $3.31 \pm 0.02$ & $2.79 \pm 0.07$ & $0.52 \pm 0.05$ & $2.41 \pm 0.03$ & $0.90 \pm 0.01$ \\
\hline
\end{tabular}

$\mathrm{SD}=$ standard deviation.

Table 4. Bacterial adhesion to the surface of epithelial cells from human buccal mucosa

\begin{tabular}{lccc}
\hline Strain & \multicolumn{3}{c}{ Buccal cells adhesion } \\
\cline { 2 - 4 } & Mean $^{\mathbf{1}}$ & \pm & Standard deviation $^{\mathbf{1}}$ \\
\hline $06 \mathrm{~T}$ & 38.57 & \pm & 20.16 \\
$09 \mathrm{~T}$ & 39.78 & \pm & 23.96 \\
$10 \mathrm{~T}$ & 30.78 & \pm & 18.79 \\
$15 \mathrm{~T}$ & 24.36 & \pm & 11.81 \\
16T & 10.13 & \pm & 7.55 \\
A. baumannii $^{2}$ & 11.10 & \pm & 7.70
\end{tabular}

${ }^{1}$ Mean and standard deviation of the number of A. baumannii adhered/ epithelial cells. ${ }^{2}$ ATCC 14606. with pathogenicity, because it is also involved in bacterial adhesion to cellular and inert surfaces [28]. We evaluated the hydrophobicity of the strains' cellular surfaces by quantitative tests of affinity to xylene. Strains 06T and $15 \mathrm{~T}$ gave the highest values, higher than that of the control strain (A. baumannii ATCC 14606). Strains $10 \mathrm{~T}$ and $16 \mathrm{~T}$ gave intermediate hydrophobicity values, whereas strain 09T had hydrophilic behavior. A wide variation in the degree of hydrophobicity was also noted in previous studies, in which the investigators suggested that clinical strains had higher hydrophobicity than did strains isolated from the environment [29].

In our study, tests for adhesion to latex, polystyrene, formica and glass surfaces were carried out because these materials are present in all hospital environments. The strains 
had similar adhesion patterns to the various materials, with the exception of glass, to which the bacteria adhered more weakly or did not adhere at all. We found that the strains had different adhesion patterns. These observations are in accordance with those of other investigators [30], who observed weaker adhesion to glass than to other materials, in a study of Gram-negative and Gram-positive bacteria. This adhesion pattern can be explained by the composition of the materials that were tested. Glass, for example, has a high concentration of silica, which makes it highly hydrophilic. The other materials are polymers; latex is a composite derived from isoprene [31], formica is composed of layers of paper covered with resin, phenol-formaldehyde polymers and ureaformaldehyde [32], and polystyrene is a styrene polymer [33]. All these materials have hydrophobic characteristics. The free energy of the materials may also account for their adhesion capacity [34]. Thus, the weak bacterial adhesion we found to glass could be due to its high free energy.

Previously, in vitro studies revealed that A. baumannii can survive more than four months on dry surfaces [35]; adequate hygiene and disinfection methods are necessary to remove these bacteria from dry surfaces in hospital environments [7]. The association between their adhesion to different materials and their survival ability on dry surfaces make these microorganisms important infectious agents. Knowledge of their adhesion properties to inanimate surfaces is of extreme importance in the hospital environment, since this bacterium has been found not only on the hands of staff but also on gloves, hospital instruments, stretchers, bed frames and bed linen $[35,36]$.

Bacterial adhesion to intravascular catheters is a factor in the propensity for the development of bacteremias and septicemias [27]. Independent of the clinical situation, the catheterized patient is often medicated with antimicrobial agents. Consequently, we evaluated in vitro the adhesion ability of A. baumanni to a catheter after treatment of the bacterial strains with sub-minimum inhibitory doses of meropenem, because these concentrations are incapable of killing bacteria, but they can affect properties associated with bacterial virulence [37]. We noted significant reductions in the number of bacteria adhered to the catheter when treated with sub-minimum inhibitory concentrations of antibiotics, confirming that meropenem interferes with the adhesion properties of the bacterial strains.

We found variations in the pattern of adhesion to the buccal epithelium cells that did not relate to any of the other parameters evaluated. These results are due to a phenomenon that is independent of the strain's hydrophobic phenotype. We should also consider other factors, such as the load on the surface and surface tension [23]. Sechi et al. [38] suggested that a genetic relationship would explain why some strains of A. baumannii had greater adhesion to cells. It is possible that the strains' genetic relationships are also associated with the adhesion phenomenon [38]. The identification of various adhesins on the cellular surface of $A$. baumannii suggests that these structures participate in the cellular adhesion process [39,40].

Through molecular typing, we found three different clones of Acinetobacter baumannii. However, there was no association between the strains' clone and its hydrophobicity degree and adhesion to abiotic and cellular surfaces.

In conclusion, there was a direct relationship between the cellular surface hydrophobicity level of the strains and adhesion to the abiotic surfaces. On the other hand, there was no direct relationship between adhesion to the abiotic surfaces and adhesion to the buccal epithelium cells, suggesting that different mechanisms are involved in adherence to the different surfaces. However, our study should be expanded, using more strains from different origins and possibly other bacterial species to help understand the success of specific Acinetobacter baumannii strains in the hospital environment.

\section{Acknowledgments}

We thank Dr. Janet W. Reid for revision of the English text.

\section{References}

1. Schreckenberger P.C., Graevenitz A. Acinetobacter, Achomobacter, Alcaligenes, Moraxella, Methylbacterium, and other non-fermentative Gram-negative roads. In: Murray P.R., Baron E.J., Pfaller, M.A., et al. eds. Manual of Clinical Microbiology. Washington: ASM press, 1999.

2. Bergogne-Bérézin E., Towner K.J. Acinetobacter spp. as nosocomial pathogens: microbiological, clinical, and epidemiological features. Clin Microbiol Rev 1996;9:148-65.

3. Dalla-Costa L.M., Coelho J.M., Souza H.A.P.H., et al. Outbreak of carbapenem-resistant Acinetobacter baumannii producing the OXA-23 enzyme in Curitiba, Brazil. J Clin Microbiol 2003;41:3403-6.

4. Larson E.L. Persistant carriage of Gram-negative bacteria on hands. Am J Infect Control 1981;9:112-9.

5. Beck-Sagué C.M., Jarvis W.R., Brook J.H., et al. Epidemic bacteremia due to Acinetobacter baumannii in five intensive care units. Am J Epidemiol 1990;132:723-33.

6. Patterson J.E., Vecchio J., Pantelick E.L., et al. Association of contaminated gloves with transmission of Acinetobacter calcoaceticus var. anitratus in an intensive care unit. Am J Med 1991;91:479-83.

7. Jawad A., Seifert H., Snelling A.M., et al. Survival of Acinetobacter baumannii on dry surfaces: Comparison of outbreak and sporadic isolates. J Clin Microbiol 1998;36:1938-41.

8. Catalano M., Quelle L.S., Jeric P.E., et al. Survival of Acinetobacter baumannii on bed rails during an outbreak and during sporadic cases. J Hosp Infect 1999;42:27-35.

9. Gallego L., Canduela M.J., Sevillano E., et al. Detección de carbapenemasas en clones de Acinetobacter baumannii resistentes a imipenem. Enferm Infect Microbiol Clin 2004;22:262-6. 
10. Foster D.H., Daschner F.D. Acinetobacter species as nosocomial pathogens. Eur J Clin Microbiol Infect Dis 1998;17:73-7.

11. Gulati S., Kapil A., Das B., et al. Nosocomial infections due to Acinetobacter baumannii in a neurosurgery ICU. Neurol India 2001;49:134-7.

12. Koljalg S., Vuopio-Varkila J., Lyytikainen O., et al. Cell surface properties of Acinetobacter baumannii. APMIS 1996; $104: 659-65$.

13. Hostacka A. Effect of aminoglycosides on surface hydrophobicity of Acinetobacter baumannii. Acta Microbiol Immunol Hung 2000; 47:15-20.

14. Bouvet P.J., Grimont P.A. Identification and biotyping of clinical isolates of Acinetobacter. Ann Inst Pasteur Microbiol 1987;138:569-78.

15. Rohlf F.J. On applications of geometric morphometrics to studies of ontogeny and phylogeny. Syst Biol 1998;47:147-58.

16. Donald H.M., Scaife W., Amyes S.G.B., Young H.K. Sequence analysis of ARI-1, a novel OXA $\beta$-Lactamase, responsible for imipenem resistance in Acinetobacter baumannii 6B92. Antimicrob Agents Chemother 2000;44:196-9.

17. Versalovic J., Koeuth T., McCabe E.R.B., Lupski J. Use of Polymerase Chain Reaction for physical mapping of Escherichia coli genes. J Bacteriol 1991;137:5253-5.

18. Versalovic J., Koeuth T., Lupski J. Distribution of repetitive DNA sequences in eubacteria and application to fingerprinting of bacterial genomes. Nucleic Acids Res 1991;19:6823-31.

19. Teixeira L.A., Figueiredo A.M., Ferreira B.T., et al. Sialic acid and surface hydrophobicity of group B streptococci. Epidemiol Infect 1993; 110:87-94.

20. Jones D.S., Adair C.G., Mawhinney W.M., Gorman S.P. Standardization and comparison of methods employed for microbial cell surface hydrophobicity and charge determination. Int J Pharm 1996;131:83-9.

21. Rosemberg M. Bacterial adherence to polystyrene: a replica method of screening for bacterial hydrophobicity. Appl Environ Microbiol 1981;42:375-7.

22. Sheth N.K., Franson T.R., Rose H.D., et al. Colonization of bacteria on polyvinyl chloride and teflon intravascular catheters in hospitalized patients. J Clin Microbiol 1983; 18 : 1061-3.

23. Ledesma A.M.M., Actis L. Propiedades de superficie y aderencia de cepas de Acinetobacter baumannii. Acta Bioq Clin Latinoam 1992;XXVI:231-9.

24. Gales A.C., Jones R.N., Forward K.R., et al. Emerging importance of multidrug-resistant Acinetobacter species and Stenotrophomonas maltophilia as pathogens in seriously ill patients: geographic patterns, epidemiological features, and trends in the SENTRY antimicrobial surveillance program (1997-1999). Clin Infect Dis 2001;32(Suppl 2):104-13.
25. Gales A.C., Tognim M.C.B., Reis A.O., et al. Emergence of an IMP-like Metallo-enzyme in an Acinetobacter baumannii clinical strains from a brazilian teaching hospital. Diag Microbiol Infect Dis 2003;45:77-9.

26. Tognim M.C.B., Andrade S.S., Silbert S., et al. Resistance trends of Acinetobacter spp. in Latin America and characterization of international dissemination of multi-drug resistant strains: five year report of the SENTRY antimicrobial surveillance program. Int J Infect Dis 2004;8:284-91.

27. Paragioudaki M., Stamouli V., Kolonitsiou F., et al. Intravenous catheter infections associated with bacteraemia: a 2-year study in a University Hospital. Clin Microbiol Infect 2004; 10:431-5.

28. Absolon D.R The role of bacterial hydrophobicity in infection: bacterial adhesion and phagocytis ingestion. Can J Microbiol 1988; $34: 287-9$.

29. Boujafaar N., Freney J., Bouvet P.J.M., Jeddi M. Cell surface hidrophobicity of 88 clinical strains of Acinetobacter baumannii. Res Microbiol 1990;141:477-82.

30. Egwari L.O., Taiwo M.A. Survival and surface ability of bacterial pathogens in oral liquid pharmaceuticals and their containers. West Indian Med J 2004;53:164-9.

31. Lehrman E. Understanding latex allergy and glove chemistry (1996), http://www.immune.com/rubber/nr3.html. Cited 16 Oct 2004.

32. Rocha W.X Química 2000 (1999), http://www.geocities.com/ Vienna/Choir/9201/polimeros.htm. Cited 16 Oct 2004.

33. Gorni A.A. Introdução aos plásticos (2004), http:// www.gorni.eng.br/intropol.html. Cited 23 Oct 2004.

34. van Pelt A.W.J., Weerkamp A.H., Uyen M.H.W.J., et al. Adhesion of Streptococcus sanguis $\mathrm{CH} 3$ to polymers with different surface free energies. Appl Environ Microbiol 1985;49:1270-5.

35. Wendt C., Dietze B., Dietz E., Rüden H. Survival of Acinetobacter baumannii on dry surfaces. J Clin Microbiol 1997;35:1394-7.

36. Berlau J., Aucken H., Malnick H., Pitt T. Distribution of Acinetobacter baumannii species on skin of healthy humans. Eur J Clin Microbiol Infect Dis 1999;18:179-83.

37. Hostacka A. Alteration on surface hidrophobicity of Acinetobacter baumannii induced by meropenem. Folia Microbiol (Praha) 1999;44:267-70.

38. Sechi L.A., Karadenizli A., Deriu A., et al. PER-1 type betalactamase production in Acinetobacter baumannii is related to cell adhesion. Med Sci Monit 2004;10:180-4.

39. Tomaras A.P., Dorsey C.W., Edelmann R.E., Actis L.A. Attachment to and biofilm formation on abiotic surfaces by Acinetobacter baumannii: involvement of a novel chaperone usher pili assembly system. Microbiology 2003;149:3473-84.

40. Ishii S., Koki J., Unno H., Hori K. Two morphological types of cell appendages on a strongly adhesive bacterium, Acinetobacter sp. Strain Tol 5. Appl Environ Microbiol 2004;70:5026-9. 